\title{
Additions to the genus Trapelia (Trapeliaceae: lichenised Ascomycetes)
}

\author{
Gintaras Kantvilas ${ }^{\mathrm{A}, \mathrm{D}}$, Steven D. Leavitt ${ }^{\mathrm{B}}$, John A. Elix ${ }^{\mathrm{C}}$ and H. Thorsten Lumbsch ${ }^{\mathrm{B}}$ \\ ATasmanian Herbarium, PO Box 5058, UTAS LPO, Sandy Bay, Tas. 7005, Australia. \\ ${ }^{B}$ Science \& Education, The Field Museum, 1400 South Lake Shore Drive, Chicago, IL 60605, USA. \\ ${ }^{C}$ Research School of Chemistry, Building 137, Australian National University, Canberra, ACT 0200, Australia. \\ ${ }^{\mathrm{D} C}$ Corresponding author. Email: gintaras.kantvilas@tmag.tas.gov.au
}

\begin{abstract}
Two new species in the genus Trapelia, namely, T. calvariana Kantvilas \& Lumbsch from the Tasmanian highlands and T. thieleana Kantvilas \& Lumbsch from south-western Western Australia, are described. Examination of ascus types and analyses of DNA-sequence data confirmed the inclusion of these taxa in Trapelia sensu lato, but raised questions concerning the homogeneity of the genus as currently circumscribed and, in particular, the generic classification of T. lilacea Kantvilas \& Elix.
\end{abstract}

Additional keywords: asci, Australia, biodiversity, Tasmania, taxonomy.

Received 8 October 2014, accepted 30 January 2015, published online 29 June 2015

\section{Introduction}

Trapeliaceae is a small, widely distributed family of chiefly crustose, squamulose or placodioid lichens. It was studied morphologically as Agyriaceae (Lumbsch 1997) and, subsequently, re-circumscribed after it was shown that the non-lichenised type species of the type genus of Agyriaceae is unrelated to the lichenised taxa placed in the family (Lumbsch et al. 2007b). The family was originally included in the order Agyriales and then moved to Baeomycetales, but is currently classified in its own order Trapeliales (Hodkinson and Lendemer 2011). In addition to Agyrium Fr., Anzina Scheid., which was included in Agyriaceae by Lumbsch (1997), has subsequently been shown to be unrelated and holds an uncertain position in Ostropomycetidae (Wedin et al. 2005; Lumbsch et al. 2007a, 2007b; Lumbsch and Huhndorf 2010). Likewise, the genus Ainoa I. Schmitt \& Lumbsch, which was described later (Lumbsch et al. 2001), has been shown to be unrelated and is now placed in Baeomycetales (Lumbsch et al. 2007a, 2007b; Schmitt et al. 2010). The family in its current circumscription is well represented in Australia by 9 of the 13 genera recognised, including Coppinsia Lumbsch \& Heibel, Lambiella Hertel, Lithographa Nyl., Placopsis (Nyl.) Lindsay, Placynthiella Elenkin, Rimularia Nyl., Trapelia M.Choisy, Trapeliopsis Hertel \& Gotth.Schneid. and Xylographa (Fr.) Fr.

The genus Trapelia, based on Lecidea coarctata Sm., was introduced by Choisy (1949) but not widely taken up until re-instated by Hertel (1969) at the time when the large 'form genus' Lecidea Ach. began to be broken up into more natural units on the basis of anatomical details of the ascomata and, in particular, the ascus (Hafellner 1984). The genus essentially consists of lichens with a Chlorella-type photobiont, hemiangiocarpic apothecia that burst through the upper surface of the thallus, a reduced, cupulate excipulum composed of prosoplectenchymatous hyphae, eight-spored, hemiamyloid (Baral 1987) asci in which the tholus typically lacks internal amyloid structures, simple ascospores, richly branched paraphyses and bacilliform to filiform conidia (Lumbsch and Kainz 2004; Kantvilas and Elix 2007; Smith et al.2009). Most taxa also contain depsides related to gyrophoric acid. McCarthy (2014) recorded five species for Australia, including the widespread, probably cosmopolitan $T$. coarctata (Sm.) M. Choisy and T. glebulosa (Sm.) J.R. Laundon, the Australasian T. macrospora Fryday, and two southern Australian endemics, T. crystallifera Kantvilas \& Elix and T. lilacea Kantvilas \& Elix. Here, we describe two further Australian taxa and discuss some aspects of the delimitation and potential heterogeneity of the genus.

\section{Materials and methods \\ Morphology, anatomy and chemistry}

The study is based chiefly on collections of the authors, housed in the Tasmanian Herbarium (HO) and the Australian National Herbarium (CANB). Descriptions are based on hand-cut sections of the thallus and ascomata examined with high-power light microscopy. Mounting media included water, $15 \% \mathrm{KOH}(\mathrm{K})$, Lugols iodine after pretreatment with $\mathrm{K}$ (IKI), lactophenol cotton blue, ammoniacal erythrosin and $50 \% \mathrm{HNO}_{3}(\mathrm{~N})$. Dimensions of asci and ascospores are based on 20 and 70 observations, respectively. The latter are presented in the format: 5 th percentile-average-95th percentile; outlying 
extreme values are given in parentheses. Routine chemical investigation used thin-layer chromatography and followed standard methods (Orange et al. 2001). The determination of critical compounds was undertaken using high-performance liquid chromatography (Feige et al. 1993).

\section{Molecular studies and phylogenetic analyses}

Data matrices of 64 sequences of 20 Trapeliaceae species were assembled using sequences of mitochondrial small-subunit, nuclear large-subunit and ITS rDNA sequences (Table 1). Two species of Xylographa were used as the out-group because this genus was shown previously to be distantly related to Trapelia within the family (Schmitt et al. 2003; Lumbsch et al. 2005; Miadlikowska et al. 2014).

DNA was extracted from a small piece of thallus or apothecial material free from visible damage or contamination, using the USB PrepEase Genomic DNA Isolation Kit (USB, Cleveland, $\mathrm{OH}, \mathrm{USA}$ ) and following the manufacturer's recommendations. Dilutions $\left(10^{-1}\right.$ up to $\left.10^{-2}\right)$ of DNA were used for polymerase chain reaction (PCR) amplifications. Primers for amplification were as follows: (1) for nuLSU rDNA: nu-LSU-0155-50 (= AL2R; Döring et al. 2000), AL2R (Mangold et al. 2008), LR5 and nu-LSU-1125-30 (= LR6; Vilgalys and Hester 1990); (2) for the mtSSU rDNA: mrSSU1 (Zoller et al. 1999) and MSU7 (Zhou and Stanosz 2001); and (3) for ITS: ITS1F (Gardes and Bruns 1993) and ITS4 (White et al. 1990). PCR conditions were as reported previously (Leavitt et al. 2012), and Ready-To-Go PCR Beads were used (GE Healthcare, Pittsburgh, PA, USA). Products were visualised on $1 \%$ agarose gel and cleaned using ExoSAP-IT (USB, Cleveland, OH, USA). Complementary strands were sequenced using BigDye v3.1
(Applied Biosystems, Foster City, CA, USA) and the same primers as used for amplifications. Sequenced PCR products were run on an ABI 3730 automated sequencer (Applied Biosystems) at the Pritzker Laboratory for Molecular Systematics and Evolution at the Field Museum, Chicago, IL, USA.

Alignments for the single datasets were carried out using Clustal W (Thompson et al. 1994) and ambiguously aligned regions (in the ITS dataset only) were manually excluded. The alignments were analysed by maximum likelihood (ML) (Felsenstein 1981) and a Bayesian approach (B/MCMC; Huelsenbeck et al. 2001). To test for potential conflict, ML bootstrap analyses were performed on each individual dataset, and $75 \%$ bootstrap consensus trees were examined for conflict (Lutzoni et al. 2004). ML analyses were performed using the program RAxML (Stamatakis 2006). The analyses were performed assuming the general time-reversible model of nucleotide substitution (Rodríguez et al. 1990), including estimation of invariant sites and assuming a discrete gamma distribution with six rate categories $(\mathrm{GTR}+\mathrm{I}+\mathrm{G})$. Gaps were treated as missing data. Bootstrapping (Felsenstein 1985) was performed on the basis of 2000 pseudoreplicates, with 200 random sequence additions.

The B/MCMC analyses were carried out using MrBayes 3.1.2 (Huelsenbeck and Ronquist 2001). The analyses were performed assuming the same model of nucleotide substitution as in the ML analysis. The dataset was partitioned into the three parts (nuLSU, mtSSU, ITS) and each partition was allowed to have its own parameters (Nylander et al. 2004). A run with 6000000 generations, starting with a random tree and employing 12 simultaneous chains, was executed. Every 100th tree was saved into a file. The first 400000 generations (i.e. the first

Table 1. Species and specimens used in the current study, with GenBank accession numbers

Newly obtained sequences are in bold

\begin{tabular}{|c|c|c|c|c|}
\hline Species & Sample & $\mathrm{mtSSU}$ & ITS & nuLSU \\
\hline Lambiella psephota & - & DQ871019 & - & DQ871012 \\
\hline Placopsis cribellans & - & DQ871018 & - & DQ871010 \\
\hline Placopsis perrugosa & - & AY584716 & HQ650709 & AF356660 \\
\hline Placynthiella icmalea & - & AY212870 & AF274082 & AY212846 \\
\hline Placynthiella uliginosa & - & DQ986877 & HQ650633 & DQ986774 \\
\hline Trapelia calvariana & Australia, Tasmania, Kantvilas 129/12 (holotype, HO) & NEW & NEW & NEW \\
\hline Trapelia coarctata & - & AY212874 & - & AF274117 \\
\hline Trapelia glebulosa & - & AF381568 & AF274080 & AF274098 \\
\hline Trapelia lilacea & Australia, Tasmania, Kantvilas 245/11 (HO) & NEW & NEW & NEW \\
\hline Trapelia lilacea & Australia, Tasmania, Kantvilas 355/05(HO) & NEW & NEW & NEW \\
\hline Trapelia placodioides & - & AF431962 & AF274081 & AF274103 \\
\hline Trapeliopsis percrenata & - & AY212876 & NEW & AF279302 \\
\hline Xylographa parallela & - & KF360445 & KF360416 & KF360476 \\
\hline Xylographa vitiligo & - & AY212878 & NEW & AY212849 \\
\hline
\end{tabular}


4000 trees) were deleted as the 'burn-in' of the chain. We used AWTY (Nylander et al. 2008) to compare split frequencies in the different runs and to plot cumulative split frequencies to ensure that stationarity was reached. Of the remaining trees, a majority rule consensus tree with average branch lengths was calculated using the sumt option of MrBayes. Posterior probabilities were obtained for each clade. Only clades that received bootstrap support equal or above $75 \%$ under ML and posterior probabilities equal or above 0.95 were considered as strongly supported. Phylogenetic trees were drawn using the program Treeview (Page 1996).

The alternative hypothesis of monophyly of the genus Trapelia was tested using the (1) Shimodaira-Hasegawa ( $\mathrm{SH}$; Shimodaira and Hasegawa 2001) and (2) expected likelihood weight (ELW) tests (Strimmer and Rambaut 2002), using the program Tree-PUZZLE v.5.2 (Schmidt et al. 2002). The program used the concatenated dataset to compare the best tree from the alternative hypotheses with the unconstrained ML tree. These trees were inferred in Tree-PUZZLE, using the $G T R+I+G$ nucleotide substitution model.

\section{Results and discussion}

\section{Phylogenetic relationships}

Eighteen new DNA sequences were obtained for the present study. The combined alignment of the nuLSU, ITS and mtSSU rDNA included 1408 unambiguously aligned nucleotide-position characters. The ML tree did not contradict the Bayesian tree topologies and, hence, only the ML tree is shown here (Fig. 1).
The phylogenetic relationships of previously studied taxa agree well with those from other studies and are not discussed further here (Schmitt et al. 2003; Wedin et al. 2005; Lumbsch et al. 2007a; Schmitt et al. 2009; Miadlikowska et al. 2014). Trapelia calvariana clustered with species of Trapelia s.str. with strong support $(97 \% / 0.99)$. This clade includes $T$. coarctata, the generitype, two other widespread species, T. glebosa and T. placodioides Coppins \& P.James (the latter not present in Australia), and the southern African T. chiodectonoides Brusse. However, the two other Australian species, viz. T. lilacea and the newly described T. thieleana, do not fall within Trapelia s.str., but diverge from this clade separately. The sister-group relationship to the clade that included Aspiciliopsis, Orceolina, Placopsis and Trapelia s.str. lacks support for T. thieleana, whereas the placement of $T$. lilacea is supported $(87 \% / 0.97)$. Monophyly of Trapelia is significantly $(P<0.001)$ rejected by alternative hypothesis testing in both tests. These results demonstrated that our knowledge of the phylogenetic diversity of Trapeliaceae in Australia is poor and that additional sampling will be necessary to elucidate whether hitherto unrecognised lineages at the generic level occur in the area.

The new species

Trapelia calvariana Kantvilas \& Lumbsch, sp. nov.

Trapeliam lilaceam Kantvilas et Elix aliquantum admonens sed excipulo annulari paraplechtenchymato, ascosporis parvioribus, 11-18 $\mu \mathrm{m}$ longis, 5-9.5 $\mu \mathrm{m}$ latis, conidiis magnioribus, 16-30 $\mu \mathrm{m}$ longis, et acidum 5-O-methylhiascicum solum continenti differt.

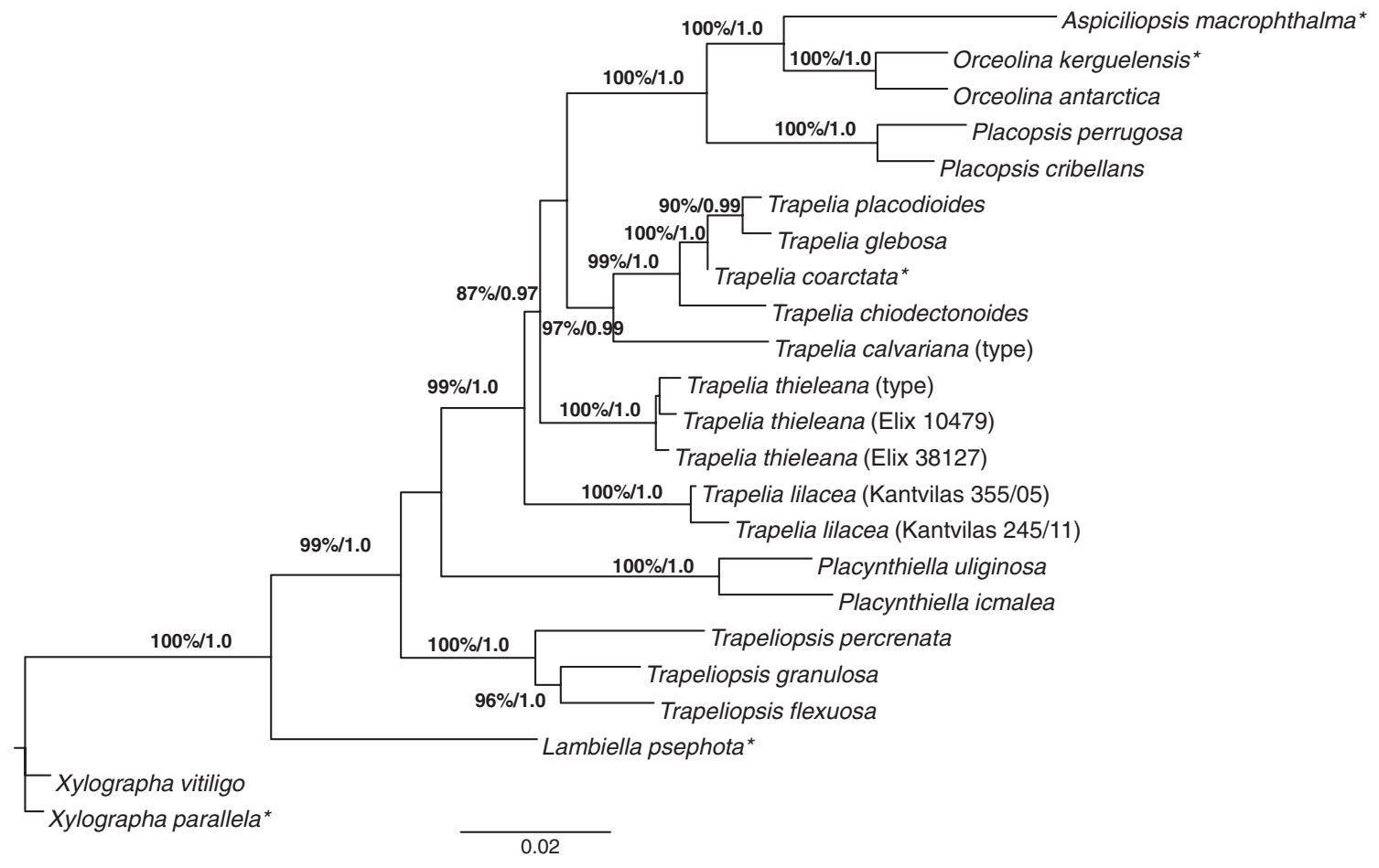

Fig. 1. Maximum likelihood (ML) tree, illustrating relationships among species of Trapelia and related genera with a partitioned dataset of three loci (mtSSU, nuLSU and nuITS). Type species of genera are indicated by an asterisk. Numbers at branches indicate ML-bootstrap values equal or above $75 \%$ before dash and posterior probabilities equal or above 0.95 after slash. 
Mycobank number: MB 811608.

Type: Australia, Tasmania: Skullbone Plains, $42^{\circ} 02^{\prime} \mathrm{S}$, $146^{\circ} 19^{\prime} \mathrm{E}, 1000-\mathrm{m}$ altitude, on boulders in open heathland, 29 February 2012, G. Kantvilas 129/12 (holo: HO; iso: F).

Thallus crustose, deeply rimose-areolate, forming irregular, widely spreading patches up to $10 \mathrm{~cm}$ wide. Individual areoles $0.2-0.8 \mathrm{~mm}$ wide, $0.2-0.65 \mathrm{~mm}$ thick, angular, plane or with the edges slightly lifting, abutting each other, but delimited by deep cracks, pale to dark grey to brown-grey, dull, sometimes a little abraded and scabrid; upper cortex poorly delimited, 10-25 $\mu \mathrm{m}$ thick, consisting of brownish, conglutinated, short-celled hyphae 2-4 $\mu \mathrm{m}$ thick; photobiont a green alga approximating Chlorella s.lat., with globose, hemispherical or irregularly rhomboid cells, 6-15 $\mu \mathrm{m}$ wide, single-celled or in pairs or tetrads and encased in a gelatinous sheath 1-2 $\mu \mathrm{m}$ thick; medulla whitish, I-. Prothallus absent. Apothecia lecideine, scattered, at first immersed in the thallus but soon emergent, sometimes retaining a thin, whitish, discontinuous rim of adhering thalline fragments, basally constricted and sessile, more rarely adnate and nestled among the thallus areoles, $(0.2-) 0.5-0.8 \mathrm{~mm}$ wide, roundish, sometimes fused in groups of 2-5 to form compound apothecia up to $1 \mathrm{~mm}$ wide and then a little angular in shape; disc black, plane at first, soon becoming convex, cracked, scabrid to verruculose, rarely \pm gyrose; proper excipulum black, matt, thin, sometimes barely evident, in section annular, 10-20 $\mu \mathrm{m}$ thick, dark brown, comprised of densely packed, rather cellular hyphae up to 5-8 $\mu \mathrm{m}$ wide. Hypothecium 50-150 $\mu \mathrm{m}$ thick, pale yellowishbrown to pale orange-brown, pigment intensifying in $\mathrm{K}$ and N. Hymenium 90-120 $\mu \mathrm{m}$ thick, separating readily in $\mathrm{K}$, colourless to pale yellowish-brown, overlain by a more intensely olive-pigmented epithecial layer up to $\sim 10 \mu \mathrm{m}$ thick, intensifying olive in $\mathrm{K}$ and N. Asci 8-spored, 65-90 $\times$ 15-19 $\mu \mathrm{m}$, often with a long tapering tail, of the Trapelia-type: elongate-clavate, with a non-amyloid or at most weakly amyloid tholus and a thin, external, amyloid sheath; ocular chamber lacking; ascoplasm with a \pm truncate apex when young. Paraphyses $1.5-2 \mu \mathrm{m}$ thick, sparsely branched and anastomosed, entangled, with apices unpigmented and not or only barely enlarged. Ascospores simple, hyaline, thin-walled, non-halonate, ellipsoid to subglobose, typically with a very prominent vacuole, 11-13.9-16(-18) × (5-)6-7.3-9(-9.5) um. Pycnidia immersed, scattered, visible as minute black glossy specks $\sim 0.05 \mathrm{~mm}$ wide, pierced by a tiny hole; conidia filiform, straight, sigmoid or curved, $16-30 \times 0.5 \mu \mathrm{m}$. Chemistry: 5-O-methylhiascic acid. (Figs 2A, B, 3A.)

\section{Etymology}

The specific epithet (calvaria, meaning 'skull' in Latin) alludes to the type locality (Skullbone Plains) and general area where most collections of this species were made.

\section{Remarks}

At first sight, this new species is reminiscent of typical forms of the widespread Tasmanian alpine lichen, Trapelia lilacea. Both taxa share an often dull, greyish thallus, small apothecia with a thin proper margin, frequently with adhering whitish thallus fragments, and 5-O-methylhiascic acid as the principal secondary chemical compound. Obvious differences between the two species are the smaller ascospores $(16-23 \times$ 9-15 $\mu \mathrm{m})$ and shorter conidia $(10-17 \mu \mathrm{m})$ of $T$. lilacea (Kantvilas and Elix 2007), as well as its more extensive, thicker thallus with plicate margins and tinges of lilac or pale yellowish-grey (shades never seen in $T$. calvariana). Furthermore, T. lilacea contains several gyrophoric acid-type compounds in trace amounts as well as two diagnostic unknown
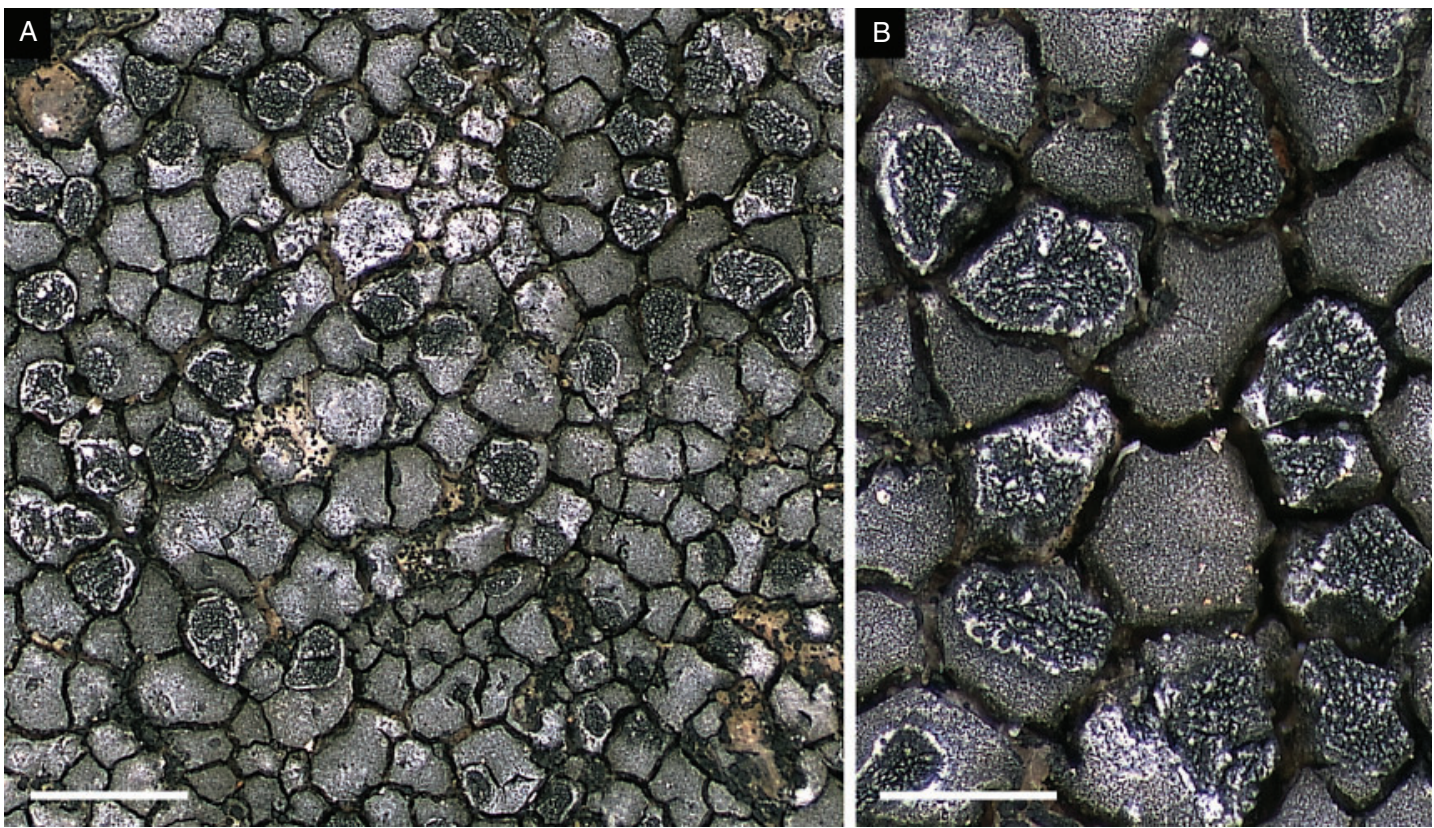

Fig. 2. Trapelia calvariana holotype. A. General habit, showing the rimose-areolate thallus with black, hemiangiocarpic apothecia; scale bar: $1 \mathrm{~mm}$. B. Detail of apothecia, showing fragments of white thalline tissue adhering to the margin; scale bar: $0.5 \mathrm{~mm}$. Photos: Jean Jarman. 


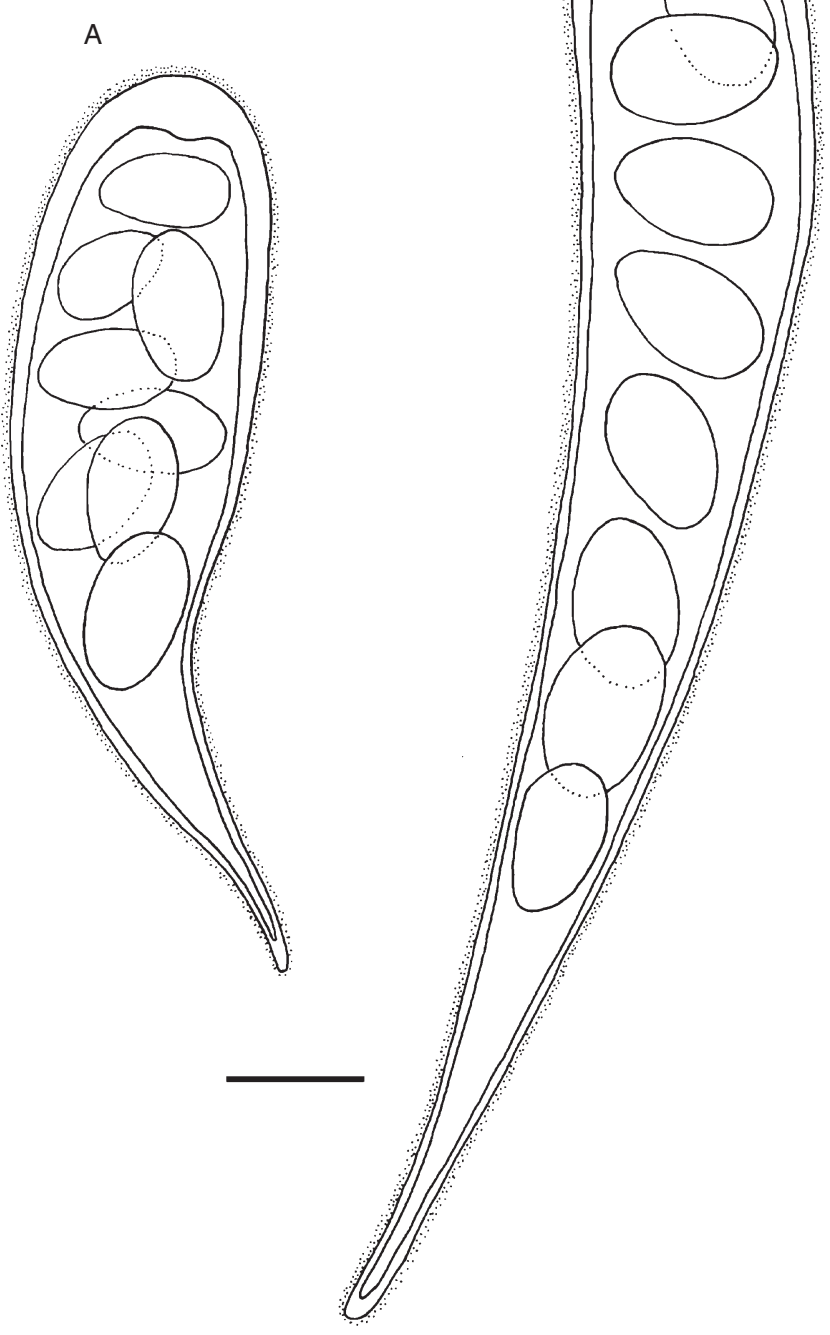

Fig. 3. Asci and ascospores (semi-schematic) with amyloid tissues stippled. A. Trapelia calvariana. B. T. thieleana. Scale bar: $10 \mu \mathrm{m}$. Line drawing: Gintaras Kantvilas.

substances that appear as UV+ yellow spots on developed thinlayer chromatography plates.

On closer scrutiny, the differences between the two taxa are even more fundamental. Their asci differ markedly. Those of $T$. calvariana accord exactly with those of $T$. coarctata, the type species of the genus, and are what are termed and illustrated as Trapelia-type (Hertel 1969, 1970; Coppins and James 1984; Lumbsch et al. 1995; Smith et al. 2009). They are elongateclavate, and have a well developed tholus that lacks any internal amyloid structures (see also Fig. 3A). In contrast, the asci of $T$. lilacea, although of the same general shape, have a tholus with amyloid flanks (Kantvilas and Elix 2007). This type of ascus has also been observed and illustrated in several species currently included in the heterogeneous genus Rimularia and the recently resurrected genus Lambiella (Coppins and Kantvilas 2001; Kantvilas and Elix 2007; Kantvilas 2014; Spribille et al. 2014). The structure of the excipulum of the two species also differs. In T. calvariana, it is annular (i.e. open beneath the hypothecium) and composed of densely packed, roundish, brown hyphal cells. This structure is rather like what is seen in Lambiella, although in that genus the excipulum is generally very thick, opaque and cupular (i.e. continuous beneath the subhymenial tissues) and extends as a 'foot' into the medulla of the thallus. In T. lilacea, the excipulum appears superficially similar to that of $T$. calvariana with respect to thickness and pigmentation, but is cupular and composed of prosoplectenchymatous hyphae.

Within the Tasmanian lichen flora, T. calvariana is a distinctive and easily identified species on account of the combination of its dark grey-brown thallus, its chemical composition, the emergent, Trapelia-like apothecia and diagnostic asci. There are numerous similarly coloured crustose lichens present; however, apart from $T$. lilacea as discussed above, all other species have starkly different ascus types and chemical composition.

In some cases, the hymenium of the new species appears to be inspersed with oil droplets, at least in the lower part. This is due to the very conspicuously vacuolate and easily ruptured ascospores, especially when in a juvenile state.

\section{Ecology and distribution}

The new species is so far known only from Tasmania, where it occurs on hard, exposed, siliceous boulders (mainly Jurassic dolerite) in heathland, grassland and sparse woodland at high elevations. It is most common in the drier, eastern parts of the Central Plateau where the annual rainfall is in the order of $900 \mathrm{~mm}$ (de Salas et al. 2014), in comparison to highland areas further to the west where the rainfall is twice as much or more. One isolated record from a rocky tor in the Tasmanian Midlands confirms the species predilection for lower rainfall sites.

In its typical, highland habitat, T. calvariana is part of a rich association of saxicolous lichens, with the more common species being Immersaria athroocarpa (Ach.) Rambold \& Pietschm., Lambiella psephota (Tuck.) Hertel, Lecanora farinacea Fée, Paraporpidia leptocarpa (C.Bab. \& Mitt.) Rambold \& Hertel, Poeltiaria coromandelica (Zahlbr.) Rambold \& Hertel, Ramboldia petraeoides (Nyl. ex C.Bab. \& Mitt.) Kantvilas \& Elix, Rhizocarpon geographicum (L.) DC., Tephromela atra (Huds.) Hafellner, and various macrolichens such as Usnea torulosa (Müll.Arg.) Zahlbr. and species of Xanthoparmelia.

\section{Additional specimens examined}

TASMANIA: Johnsons Lagoon, $41^{\circ} 59^{\prime} \mathrm{S}, 146^{\circ} 23^{\prime} \mathrm{E}, 1040-\mathrm{m}$ altitude, 2007, G. Kantvilas 394/07 (HO); Adams Peak, 41 $44^{\prime} \mathrm{S}, 146^{\circ} 41^{\prime} \mathrm{E}$, 1300-m altitude, 2009, G. Kantvilas 10/09 (HO); Bisdee Tier, $42^{\circ} 26^{\prime} \mathrm{S}, 147^{\circ} 17^{\prime} \mathrm{E}, 640-\mathrm{m}$ altitude, G. Kantvilas 197/09 (HO); Skullbone Plains, $\sim 2 \mathrm{~km} \mathrm{~S}$ of Kenneth Lagoon, $42^{\circ} 04^{\prime} \mathrm{S}, 146^{\circ} 19^{\prime} \mathrm{E}$, 990-m altitude, 2012, G. Kantvilas 223/12 (HO); $\sim 1 \mathrm{~km} \mathrm{~W}$ of Circular Marsh, $41^{\circ} 59^{\prime} \mathrm{S}, \quad 146^{\circ} 28^{\prime} \mathrm{E}, \quad 860-\mathrm{m}$ altitude, 2014, G. Kantvilas 77/14 (HO); Gowan Brae, E side of Nive River, 810-m altitude, 2014, G. Kantvilas 121/14 (HO). 
Trapelia thieleana Kantvilas, Lumbsch \& Elix, sp. nov.

Trapeliae coarctatae (Turner ex Sm.) M. Choisy similis sed superficie pigmento ignoto vitellino plerumque imbuta.

Mycobank number: MB 811609.

Type: Australia, Western Australia: Tutunup Road, $33^{\circ} 40^{\prime} \mathrm{S}$ $115^{\circ} 34^{\prime} \mathrm{E}, 35-\mathrm{m}$ altitude, on ironstone boulders in dense heathland, 13 Nov. 2011, G. Kantvilas 439/11 (holo: HO; iso: PERTH).

Thallus crustose, rimose-areolate to \pm subsquamulose, dull pale grey, mostly with a smoky or faint lilac tinge, usually flushed here and there with diffuse patches of a vivid, eggyolk yellow pigment, ecorticate, not effigurate, forming irregular patches up to $\sim 10 \mathrm{~cm}$ across and $75-250 \mu \mathrm{m}$ thick; upper surface generally even but nevertheless reflecting the texture of the substratum beneath, smooth to faintly scabrid, in yellow-pigmented areas minutely farinose; prothallus usually absent, or forming a thin, black border where a leading edge of the thallus abutts other lichens; medulla white; photobiont a unicellular green alga (Chlorella?) with cells globose or irregularly rounded, 6-12 $\mu \mathrm{m}$ wide, occurring singly, in pairs or in tetrads, usually surrounded by a gelatinous sheath. Apothecia biatorine, $0.3-0.6 \mathrm{~mm}$ wide, roundish, scattered, remaining discrete, soon emergent from the thallus, but mostly retaining adhering thalline fragments on the margin and disc; disc pale brown to grey-brown, plane to undulate to convex, often verruculose; proper excipulum concolorous with the disc, inapparent to \pm excluded, in section hyaline, $\sim 10-30 \mu \mathrm{m}$ thick at the upper edge, becoming thinner and poorly differentiated at the sides and base, composed of loosely interwoven prosoplectenchymatous hyphae. Hypothecium colourless to pale reddish-brown, $60-150 \mu \mathrm{m}$ thick. Hymenium 120-150 $\mu \mathrm{m}$ thick, colourless. Asci 8-spored, 110-140 × 12-20 $\mu \mathrm{m}$, of the
Trapelia-type: cylindrical to elongate-clavate, with a non-amyloid or at most weakly amyloid tholus and a thin, external, amyloid sheath; ocular chamber lacking; ascoplasm with a \pm truncate apex when young. Paraphyses $1.5-2 \mu \mathrm{m}$ thick, sparsely branched and anastomosed, entangled, with apices unpigmented and not enlarged. Ascospores simple, hyaline, thin-walled, nonhalonate, ellipsoid, (12-)14-16.4-19(-23) × (6.5-)8-9.7-11 $(-12) \mu \mathrm{m}$. Pycnidia immersed, scattered, visible as minute, pale pinkish-brown pits $\sim 0.05 \mathrm{~mm}$ wide in the thallus surface; conidia filiform, mostly strongly curved, $15-25 \times 0.5 \mu \mathrm{m}$. Chemistry: gyrophoric acid (major), 5-O-methylhiascic acid (minor), plus minor related unknowns; thallus $\mathrm{C}+$ red. (Figs 3B, 4A, B.)

\section{Etymology}

It is a pleasure to name this species in honour of the Western Australian botanist, Kevin Thiele, a colleague, friend, and frequent and interested companion of the first author on annual Heads of Herbaria field excursions, including the one when the type specimen of this species was collected.

\section{Remarks}

Superficially, the available collections of this species could have been included under Trapelia coarctata, a highly variable and very widely distributed (ecologically and geographically) member of the genus. Both taxa have a similar general appearance, a Chlorella-like photobiont, ascospores of a similar size and a gyrophoric acid-dominated secondary chemistry. However, T. coarctata is not known to contain any yellow pigments. That a distinct taxon was involved was confirmed by DNA-sequence data, which also indicated that the relationship between $T$. thieleana and $T$. coarctata is quite
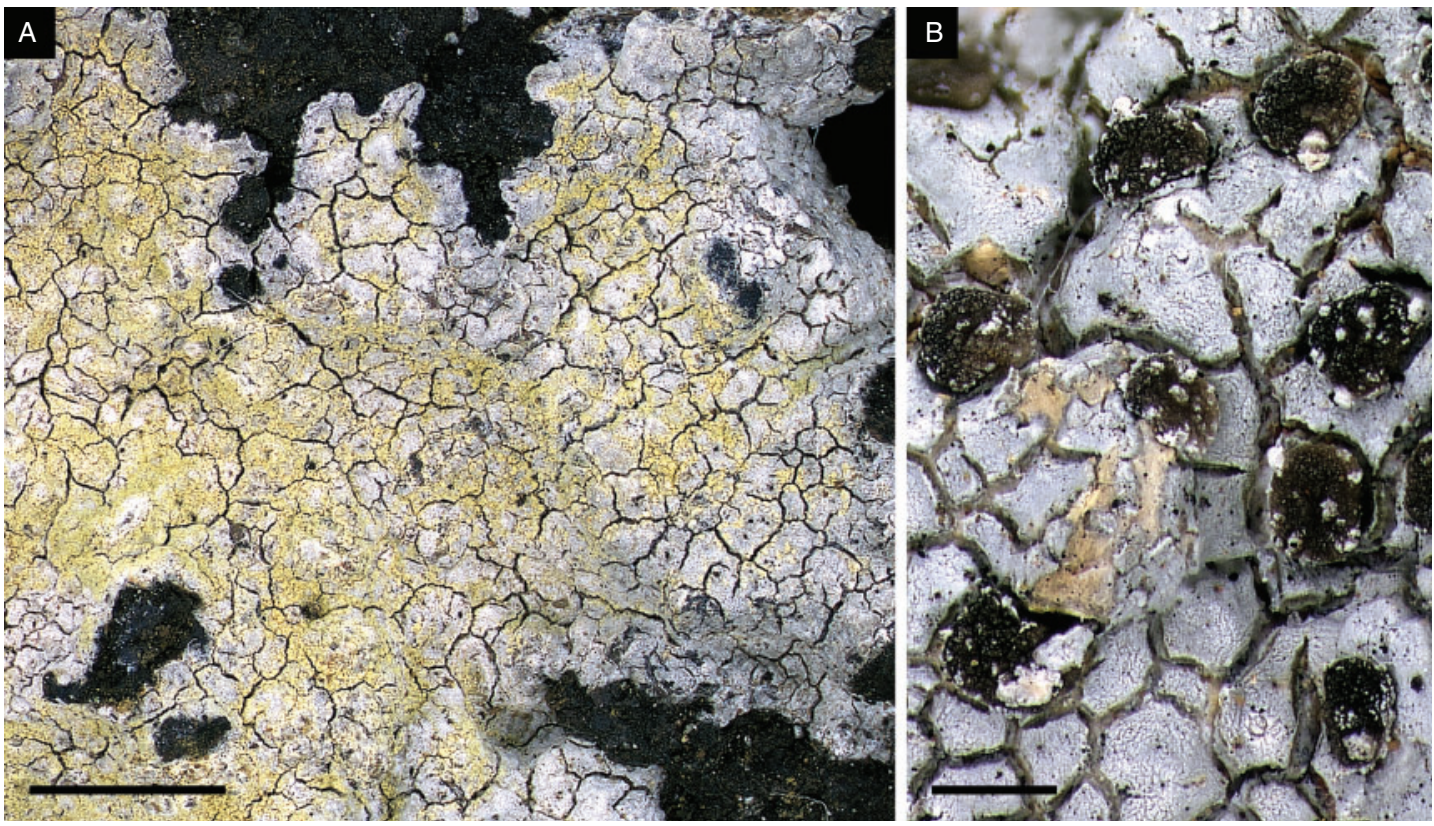

Fig. 4. Trapelia thieleana. A. General habit (holotype); scale: $2 \mathrm{~mm}$. B. detail of apothecia (Elix 38126), with adhering fragments of thalline tissue; scale bar: $0.5 \mathrm{~mm}$. Photos: Jean Jarman. 
distant. Not all specimens studied contained the yellow pigment, and indeed the single fertile specimen (JAE 38126) did not, but their conspecificity was confirmed by molecular data.

The identity of the yellow pigment is unknown. It does not show up on thin-layer chromatography plates; nor is it detected by high-performance liquid chromatography. In the section, it appears as angular-rhomboid crystals, 5-10 $\mu \mathrm{m}$ wide, that fluoresce yellow in polarised light, are greenish in transmitted light, and do not dissolve in $\mathrm{KOH}$.

The excipulum of $T$. thieleana is extremely reduced. At the upper edge, it is seen in vertical section as a slight bulge of intertwined hyphae, but with increasing depth into the apothecium, it tapers away to the point where the hymenial and medullary tissues are adjacent. In this respect, it differs from $T$. coarctata, where a thin but nevertheless distinct excipulum is evident, completely enclosing the hymenium and hypothecium. As is rather common in Trapeliaceae, some ascospores within the ascus, especially the uppermost ones, may be grossly deformed and undeveloped.

\section{Ecology and distribution}

The new species is known only from south-western Western Australia, where it occurs on granite and ironstone in open eucalypt forest and dense scrubby heathland.

\section{Additional specimens examined}

WESTERN AUSTRALIA: John Forrest National Park, Darling Ranges, $26 \mathrm{~km}$ E of Perth, 1982, J.A. Elix 10479 \& L. H. Elix (CANB); near summit of Mount Observation, $20 \mathrm{~km} \mathrm{~W}$ of York, $31^{\circ} 53^{\prime} 45^{\prime \prime} \mathrm{S}$ $116^{\circ} 33^{\prime} 26^{\prime \prime} \mathrm{E}, 365-\mathrm{m}$ altitude, 2006, J.A Elix 38126, 38127 (CANB); Koodiwoodle Range, near Bidgerabbie Hill, $30^{\circ} 48^{\prime} 14^{\prime \prime} \mathrm{S} 115^{\circ} 48^{\prime} 34^{\prime \prime} \mathrm{E}$, 200-m altitude, J.A. Elix 28978 (CANB).

\section{Acknowledgements}

We thank Jean Jarman who photographed the species illustrated in the present paper, and prepared all figures for publication. The first author also acknowledges with thanks the Australian Biological Resources Study for their support of some of the Tasmanian field and laboratory work through an Applied Taxonomy Grant under the Bush Blitz programme.

\section{References}

Baral HO (1987) Lugol's solution/IKI versus Melzer's reagent: hemiamyloidity, a universal feature of the ascus wall. Mycotaxon 29, 399-450.

Choisy M (1949) Catalogue des lichens de la region lyonnaise. Bulletin Mensuel de la Societe Linneenne de Lyon 18, 137-152. [Fasc. 2]

Coppins BJ, James PW (1984) New or interesting British lichens. V. Lichenologist 16, 241-264. doi:10.1017/S0024282984000451

Coppins BJ, Kantvilas G (2001) Four new species of Rimularia Nyl. (Agyriaceae). Bibliotheca Lichenologica 78, 35-48.

de Salas M, Baker M, Cave L, Kantvilas G (2014) Vegetation of the Skullbone Plains Property, north-west of Bronte Park. Kanunnah 7, 168-188.

Döring H, Clerc P, Grube M, Wedin M (2000) Mycobiont-specific PCR primers for the amplification of nuclear ITS and LSU rDNA from lichenized ascomycetes. Lichenologist 32, 200-204. doi:10.1006/lich.1999.0250

Feige GB, Lumbsch HT, Huneck S, Elix JA (1993) Identification of lichen substances by a standardized high-performance liquid-chromatographic method. Journal of Chromatography. A 646, 417-427. doi:10.1016/0021-9673(93)83356-W

Felsenstein J (1981) Evolutionary trees from gene-frequencies and quantitative characters: finding maximum-likelihood estimates. Evolution 35, 1229-1242. doi:10.2307/2408134

Felsenstein J (1985) Confidence-limits on phylogenies: an approach using the bootstrap. Evolution 39, 783-791. doi:10.2307/2408678

Gardes M, Bruns TD (1993) ITS primers with enhanced specificity for basidiomycetes: application to the identification of mycorrhizae and rusts. Molecular Ecology 2, 113-118. doi:10.1111/j.1365-294X.1993.tb00005.x

Hafellner J (1984) Studien in Richtung einer natürlicheren Gliederung der Sammelfamilien Lecanoraceae und Lecideaceae. Beihefte zur Nova Hedwigia 79, 241-371.

Hertel H (1969) Die Flechtengattung Trapelia Choisy. Herzogia 1, 111-130.

Hertel H (1970) Trapeliaceae: eine neue Flechtenfamilie. Vorträge aus dem Gesamtgebiet der Botanik, Neue Folge [Berichte der Deutschen Botanischen Gesellschaft] 4, 171-185.

Hodkinson BP, Lendemer JC (2011) The orders of Ostropomycetidae (Lecanoromycetes, Ascomycota): recognition of Sarrameanales and Trapeliales with a request to retain Pertusariales over Agyriales. Phytologia 93, 407-412.

Huelsenbeck JP, Ronquist F (2001) MRBAYES: Bayesian inference of phylogenetic trees. Bioinformatics 17, 754-755. doi:10.1093/bioinformatics/17.8.754

Huelsenbeck JP, Ronquist F, Nielsen R, Bollback JP (2001) Evolution: Bayesian inference of phylogeny and its impact on evolutionary biology. Science 294, 2310-2314. doi:10.1126/science.1065889

Kantvilas G (2014) New species of the genus Rimularia Nyl. from Tasmania. Lichenologist 46, 349-364. doi:10.1017/S0024282913000595

Kantvilas G, Elix JA (2007) Additions to the lichen family Agyriaceae Corda from Tasmania. Bibliotheca Lichenologica 95, 317-333.

Leavitt SD, Esslinger TL, Divakar PK, Lumbsch HT (2012) Miocene and Pliocene dominated diversification of the lichen-forming fungal genus Melanohalea (Parmeliaceae, Ascomycota) and Pleistocene population expansions. BMC Evolutionary Biology 12, 176. doi:10.1186/1471-2148-12-176

Lumbsch HT (1997) Systematic studies in the suborder Agyriineae (Lecanorales). The Journal of the Hattori Botanical Laboratory 83, 1-73.

Lumbsch HT, Huhndorf SM (2010) Myconet. Vol. 14. Part One. Outline of Ascomycota - 2009. Fieldiana 1, 1-42.

Lumbsch HT, Kainz C (2004) Trapelia. In 'Lichen Flora of the Greater Sonoran Desert Region, Vol. 2'. (Eds TH Nash, III, BD Ryan, P Diederich, C Gries, Fe Bungartz) pp. 537-538. (Lichens Unlimited, Arizona State University: Tempe, AZ)

Lumbsch HT, Lunke T, Feige GB, Huneck S (1995) Anamylopsoraceae: a new family of lichenized ascomycetes with stipitate apothecia (Lecanorales: Agyriineae). Plant Systematics and Evolution 198, 275-286. doi:10.1007/BF00984742

Lumbsch HT, Schmitt I, Doring H, Wedin M (2001) ITS sequence data suggest variability of ascus types and support ontogenetic characters as phylogenetic discriminators in the Agyriales (Ascomycota). Mycological Research 105, 265-274. doi:10.1017/S0953756201003483

Lumbsch HT, Schmitt I, Lindemuth R, Miller A, Mangold A, Fernandez F, Huhndorf S (2005) Performance of four ribosomal DNA regions to infer higher-level phylogenetic relationships of inoperculate euascomycetes (Leotiomycota). Molecular Phylogenetics and Evolution 34, 512-524. doi:10.1016/j.ympev.2004.11.007

Lumbsch HT, Schmitt I, Lücking R, Wiklund E, Wedin M (2007a) The phylogenetic placement of Ostropales within Lecanoromycetes (Ascomycota) revisited. Mycological Research 111, 257-267. doi:10.1016/j.mycres.2007.01.006

Lumbsch HT, Schmitt I, Mangold A, Wedin M (2007b) Ascus types are phylogenetically misleading in Trapeliaceae and Agyriaceae 
(Ostropomycetidae, Ascomycota). Mycological Research 111, 1133-1141. doi:10.1016/j.mycres.2007.06.016

Lutzoni F, Kauff F, Cox C, McLaughlin D, Celio G, Dentinger B, Padamsee M, Hibbett D, James TY, Baloch E, Grube M, Reeb V, Hofstetter V, Schoch C, Arnold AE, Miadlikowska J, Spatafora J, Johnson D, Hambleton S, Crockett M, Shoemaker R, Sung G-H, Lücking R, Lumbsch HT, O’Donnell K, Binder M, Diederich P, Ertz D, Gueidan C, Hansen K, Harris RC, Hosaka K, Lim Y-W, Matheny B, Nishida H, Pfister D, Rogers J, Rossman A, Schmitt I, Sipman H, Stone J, Sugiyama J, Yahr R, Vilgalys R (2004) Assembling the fungal tree of life: progress, classification, and evolution of subcellular traits. American Journal of Botany 91, 1446-1480. doi:10.3732/ajb.91.10.1446

Mangold A, Martin MP, Lücking R, Lumbsch HT (2008) Molecular phylogeny suggests synonymy of Thelotremataceae within Graphidaceae (Ascomycota: Ostropales). Taxon 57, 476-486.

McCarthy PM (2014) Checklist of the Lichens of Australia and its Island Territories. Version 23 September 2014. (Australian Biological Resources Study: Canberra, ACT) Available at http://www.anbg.gov. au/abrs/lichenlist/introduction.html [Verified 23 April 2015].

Miadlikowska J, Kauff F, Högnabba F, Oliver JC, Molnár K, Fraker E, Gaya E, Hafellner J, Hofstetter V, Gueidan C, Kukwa M, Lücking R, Björk C, Sipman HJM, Burgaz AR, Thell A, Passo A, Myllys L, Goward T, Fernández-Brime S, Hestmark G, Lendemer J, Lumbsch HT, Schmull M, Schoch C, Sérusiaux E, Maddison D, Arnold AE, Lutzoni F, Stenroos S (2014) Multigene phylogenetic synthesis for 1307 fungi representing 1139 infrageneric taxa, 312 genera and 66 families of the class Lecanoromycetes (Ascomycota). Molecular Phylogenetics and Evolution 79, 132-168. doi:10.1016/j.ympev.2014.04.003

Nylander JAA, Ronquist F, Huelsenbeck JP, Nieves-Aldrey JL (2004) Bayesian phylogenetic analysis of combined data. Systematic Biology 53, 47-67. doi:10.1080/10635150490264699

Nylander JAA, Wilgenbusch JC, Warren DL, Swofford DL (2008) AWTY (are we there yet?): a system for graphical exploration of MCMC convergence in Bayesian phylogenetics. Bioinformatics 24, 581-583. doi:10.1093/bioinformatics/btm388

Orange A, James PW, White FJ (2001) 'Microchemical Methods for the Identification of Lichens.' (British Lichen Society: London)

Page RDM (1996) Treeview: an application to display phylogenetic trees on personal computers. Computer Applications in the Biosciences 12, 357-358.

Rodríguez F, Oliver JL, Marin A, Medina JR (1990) The general stochasticmodel of nucleotide substitution. Journal of Theoretical Biology 142, 485-501. doi:10.1016/S0022-5193(05)80104-3

Schmidt HA, Strimmer K, Vingron M, von Haeseler A (2002) TREEPUZZLE: maximum likelihood phylogenetic analysis using quartets and parallel computing. Bioinformatics 18, 502-504. doi:10.1093/bioinformatics/18.3.502

Schmitt I, Lumbsch HT, Sochting U (2003) Phylogeny of the lichen genus Placopsis and its allies based on Bayesian analyses of nuclear and mitochondrial sequences. Mycologia 95, 827-835. doi:10.2307/3762011
Schmitt I, del Prado R, Grube M, Lumbsch HT (2009) Repeated evolution of closed fruiting bodies is linked to ascoma development in the largest group of lichenized fungi (Lecanoromycetes, Ascomycota). Molecular Phylogenetics and Evolution 52, 34-44. doi:10.1016/j.ympev.2009.03.017

Schmitt I, Fankhauser JD, Sweeney K, Spribille T, Kalb K, Lumbsch HT (2010) Gyalectoid Pertusaria species form a sister-clade to Coccotrema (Ostropomycetidae, Ascomycota). Mycology 1, 75-83. doi:10.1080/21501201003631540

Shimodaira H, Hasegawa M (2001) CONSEL: for assessing the confidence of phylogenetic tree selection. Bioinformatics 17, 1246-1247. doi:10.1093/bioinformatics/17.12.1246

Smith CW, Aptroot A, Coppins BJ, Fletcher A, Gilbert OL, James PW, Wolseley PA (2009) 'The Lichens of Great Britain and Ireland.' (The British Lichen Society: London)

Spribille T, Resl P, Ahti T, Pérez-Ortega S, Tønsberg T, Mayrhofer H, Lumbsch HT (2014) Molecular systematics of the wood-inhabiting, lichen-forming genus Xylographa (Baeomycetales, Ostropomycetidae) with eight new species. Symbolae Botanicae Upsalienses 37, 1-87.

Stamatakis A (2006) RAxML-VI-HPC: maximum likelihood-based phylogenetic analyses with thousands of taxa and mixed models. Bioinformatics 22, 2688-2690. doi:10.1093/bioinformatics/bt1446

Strimmer K, Rambaut A (2002) Inferring confidence sets of possibly misspecified gene trees. Proceedings of the Royal Society of London. Series B, Biological Sciences 269, 137-142. doi:10.1098/rspb.2001.1862

Thompson JD, Higgins DG, Gibson TJ (1994) CLUSTAL-W: improving the sensitivity of progressive multiple sequence alignment through sequence weighting, position-specific gap penalties and weight matrix choice. Nucleic Acids Research 22, 4673-4680. doi:10.1093/nar/22.22.4673

Vilgalys R, Hester M (1990) Rapid genetic identification and mapping of enzymatically amplified ribosomal DNA from several Cryptococcus species. Journal of Bacteriology 172, 4238-4246.

Wedin M, Wiklund E, Crewe A, Döring H, Ekman S, Nyberg Å, Schmitt I, Lumbsch HT (2005) Phylogenetic relationships of Lecanoromycetes (Ascomycota) as revealed by analyses of mtSSU and nLSU rDNA sequence data. Mycological Research 109, 159-172. doi: $10.1017 / \mathrm{S} 0953756204002102$

White TJ, Bruns TD, Lee SB, Taylor JW (1990) Amplification and direct sequencing of fungal ribosomal RNA genes for phylogenetics. In 'PCR Protocols'. (Eds MA Innis, DH Gelfand, JJ Sninsky, TJ White) pp. 315-322. (Academic Press: San Diego, CA)

Zhou S, Stanosz GR (2001) Primers for amplification of mt SSU rDNA, and a phylogenetic study of Botryosphaeria and associated anamorphic fungi. Mycological Research 105, 1033-1044. doi:10.1016/S0953-7562(08)61965-6

Zoller S, Scheidegger C, Sperisen C (1999) PCR primers for the amplification of mitochondrial small subunit ribosomal DNA of lichen-forming ascomycetes. Lichenologist 31, 511-516. doi: $10.1017 / \mathrm{S} 0024282999000663$ 